\title{
Maritime Law Development On Special Department On Sea Transportation
}

\author{
Achmad Ridwan Tentowi \\ Doctorate Candidate of Law Science on Universitas Pasundan Bandung \\ Legal development demonstrates the pattern of cooperation by involving all stakeholders in the social community. \\ In this process, legal development in Indonesia usually implies a pragmatic goal (for development) as input from \\ Roescoe Pound and Eugen Ehrlich where the correlation between Laswell and Mc Dougal's statement that \\ cooperation between legal studies and practical law bearers is ideally able to produce legal theory (theory about \\ law), a theory that has pragmatic or practical uses. Thus, the development of maritime law specifically in the field \\ of port is a pragmatic goal to reform the maritime law itself. Further, the main goal is that port has its own law, so \\ that the element of certainty and justice in the port business can be guaranteed through the constitution.
}

\begin{abstract}
DOI: $10.7176 / \mathrm{JLPG} / 84-14$

Publication date: April $30^{\text {th }} 2019$
\end{abstract}

Key words: Legal Development, Sea Transportation, Maritime

\section{INTRODUCTION}

The ability of a country to streamline the movement of people, goods and services is an important component of economic development. A country needs to have access to transportation to the market smoothly. The road that connects an area with larger cities is the main infrastructure for the development of the regional economy. Seaports have the potential to enhance further transportation relations. Maintenance of road networks, expansion of airways, waterways are needed to improve population mobility and movement of goods. Infrastructure development is needed to increase regional attractiveness and competitiveness. Recognizing the actual movement needs that need to be done in planning transportation development. That is, in order to be able to improve the economy through the Port as a means and infrastructure to support the country's economic progress, the port must have considerable competitiveness, considering that in various Asian countries, the port is the heart of a country.

The key to the success of a country's economic development is the existence of a strong and highly competitive business world. The issue of competitiveness in an increasingly open world market is a key issue and a challenge that is not easy. Therefore, efforts to increase competitiveness should be of concern to various stakeholders. Three important indicators, namely knowledge, services (service) and discipline owned by the company will be able to form the Corporate Image of the company. Corporate Image has a significant role in increasing the competitiveness of a company and corporate image can be used as a basis in shaping the national corporate image. Competitiveness is an important factor to show the existence of a country. Competitiveness is an advantage of a country that must be conveyed to the world. Indonesia as an agricultural country has a large comparative advantage that should be able to be developed and shown to the world through good products and services quality.

Based on the mandate of the Constitution, that the State of Indonesia is a legal state and not a state of power, this is contained in the constitution of the 1945 Constitution, an explanation section stating that Indonesia is a state based on law (Rechstaat) and not based on mere power ( Machtstaat). The founders of the Indonesian nation have formulated in the 1945 Constitution which states that: "Indonesia is a country based on law, not based on mere power". If we pay attention to the formulation, it contains recognition of two main elements, namely, Law and Power. These two elements in the administration of the state are inseparable from each other because in reality, the law cannot be enforced without power, whereas power without law can deviate towards a totalitarian state or autocracy and can endanger the integrity of the Republic of Indonesia. When we talk about governance, it needs to be realized that governance is one of the three elements of the "country" besides certain people and regions. The state is essentially a power organization. Power is neutral and will be positive or negative, much depends on the person or regime that holds that power.

In Max Weber's view, law is a coercive order. It is said that because the establishment of a legal order is different from other social norms and regulations that are not legal (extra legal), because the legal order is fully supported by the coercive power of the State. Another perspective states that law is interpreted as a method, or norm. The method or norm, is a benchmark or guideline regarding appropriate human behavior. On the basis of its scope, it is usually distinguished between methods governing personal interests, with methods that govern interpersonal interests. The legal procedure is classified as a method that regulates interpersonal interests. In addition, the law is also interpreted as a legal system, the legal system is positive law. 
Associated with Port Business, the umbrella for this activity is that all of them are subject to Law No. 17 of 2008 concerning Shipping, which is implemented by Government Regulation No. 61 of 2009 concerning Port. Although in substance the contents of the PP are derived from UUNo. 17 of 2008. Following up on the legal umbrella at the Port, the Government together with the legislature should have to rethink a more comprehensive legal umbrella for the port. The set of rules is considered still not prioritizing port management properly and comprehensively, which is able to provide benefits and benefits for the contribution of the State Budget in the form of dividends.

Law No. 17 of 2008 concerning Shipping, provides the foundation for comprehensive port system reform in Indonesia. What is striking is that the shipping law abolished the government monopoly on the port sector and opened opportunities for private sector participation. This can lead to the entry of much-needed competition in the port sector, creating pressure to reduce prices, and generally improve port services. Although there is maintained optimism regarding the new law, investors must now face a policy vacuum while awaiting the development of implementing regulations and supporting institutions.

\section{LITERATURE REVIEW}

Development Law Theory, influenced by the thinking of Herold D. Laswell and Myres S. Mc Dougal (Policy Approach) coupled with the theory of Law from Roscoe Pound (minus its mechanical conception). Since the beginning of his career Mochtar declared himself to be a sociological jurisprudence exponent in and for Indonesia. Therefore Mochtar's understanding can be caused by intensive readings of Roscoe Pound's works, especially the book entitled Social Control Tough Law which he discovered during his studies in the United States in 1955 1956. (Lili Rasjidi \& IB Wyasa, Law As A System, 1994). Mochtar Kusumaatmadja processed all of these inputs and adjusted them to Indonesian conditions. There was an interesting side to the theory presented by Laswell \& McDougal where it was shown the importance of cooperation between theoretical legal carriers and general scholars (scholars) as well as practical lawyers (specialists in decision) in the process gives birth to a public policy, which on the one hand is politically effective, but on the other hand is also enlightening. (Shidarta, Characteristics of Legal Reasoning in the Indonesian Context, 2006; 411.

The Legal Theory of Development from Mochtar Kusumaatmadja, demonstrates the pattern of cooperation by involving all stakeholders in the social community. In the process Mochtar Kusumaatmadja added that there was a pragmatic goal (for development) as input from Roescoe Pound and Eugen Ehrlich where the correlation between Laswell and Mc Dougal's statement that cooperation between legal studies and practical law bearers was ideally capable of producing legal theory (theory about law), a theory that has pragmatic or practical uses.

Mochtar Kusumaatmadja brilliantly changed the notion of law as a tool to become a law as a means to develop society. The main points underlying the concept are that order and order in the efforts of development and renewal are indeed desirable, even absolutely necessary, and that the law in the sense of the norm is expected to direct human activities towards the desired development and renewal. Therefore, the necessary facilities in the form of legal regulations in the form of unwritten must be in accordance with the laws that live in the community.

\section{FINDING AND DISCUSSION}

Government Regulation (PP) No. 61 of 2009 concerning Port, in substance is derived from Law No. 17 of 2008 concerning shipping. So, this is very ineffective, just moving it in the form of a Government Regulation (PP). For this purpose, in order to be able to accommodate various problems and interests contained in the Port, the author has the view that the port arrangement, specifically regulated through a separate Law, is not combined with Law No. 17 of 2008 concerning shipping, as has been true so far.

The joint arrangement in the Shipping Law is too broad and unfocused, many gray articles do not explicitly regulate the management of ports in Indonesia such as Pelindo I-IV. On the other hand, the port industry which has been managed by the PT (Persero) Pelabuhan Indonesia (Pelindo) State Enterprise, both Pelindo I (Medan), Pelindo II (Tanjung Priok), Pelindo III (Surabaya) and Pelindo IV ( Makassar), is considered not yet providing 'Community Development' or social empowerment of the surrounding community.

For comparison, just look at the Singapore State, how their efforts to raise the marine potential even though it is limited in area, so that they are one of the countries in Asia that has been taken into account the economic level. One of the revenue advocates in Singapore is the port sector. In fact, in this country it is often called the Port State. They are a place to transit world trade. The author's thinking of designing this legal concept must be 'accommodative' and 'progressive'. Of course, the form of the legal concept is poured into a law as a separate arrangement for the Port. Accommodatively, the Port Law, always deals with infrastructure which includes three (3) basic elements, namely: soft, non-physical, and physical. (Faisal Basri \& Haris Munandar, Indonesian Economic Landscape, 2009: 128). 
The importance of soft port infrastructure is the main and most important basic element, because it is 'fundamental characteristics', in the form of values (work ethic, norms, business ethics, 'fairness', and equality). This type of infrastructure, also called an 'institutional' framework or institution which includes various values (including work ethics), norms (especially those that have been developed and codified into legal regulations and legislation), and the quality of public services provided by various related parties, especially the government.

Regarding port, then soft infrastructure is a platform for port infrastructure, both non-physical and physical. Mindset, concepts, beliefs, vision, mission, and commitment to port infrastructure that are soft, become the framework and basis for thinking, attitudes, behaviors, actions, obligations, and responsibilities in setting, implementing, and evaluating strategies, policies, programs, objectives, targets, performance, and certain parameters (objective, fair), as being the Portrait of the Law (Law) which covers philosophical, sociological, juridical, and political values. Thus, port efficiency and effectiveness (Law) can reduce / minimize regulations in port / other nuances that are counterproductive because they are implemented and overlapping biases.

The port law aspired far ahead must be constructive, which can regulate all activities in the Port. This legal concept is in accordance with what was explained by Mochtar Kusumaatmadja, (Mochtar Kusumaatmadja, Law, Society, and National Law Development, 1976: 11), in his thinking, he explained that; law as a whole principles - principles and rules - rules that govern human life in society, also includes institutions - institutions (institutions) and processes (processes) that realize the enactment of the rules - rules in reality.

Responding to Mochtar Kusumaatmadja's thoughts, for the sake of establishing port law, that the upcoming Port law would want to make law 'a tool for reforming society'. The definition stated, acknowledged by Mochatar Kusumaatmadja, was in response to the needs of the community at that time that was building. The Concept of Legal Theory of Development from Mochtar Kusumaatmadja, can be used as a reference in developing the Port Maritime Law. Mochtar Kusumaatmadja, views the concept of law as a means of renewing society, as adoption adapted to Indonesian conditions from the law as his "tool" Roscoe Pound. Law as a means of reaching out more broadly and in its scope of law as a tool because:

1. In Indonesia the role of legislation in the legal renewal process is more prominent, for example when compared to the United States which places jurisprudence (especially the Supreme Court verdict) in a more important place; 2. The concept of law as a "tool" will result in results that are not much different from the application of "legism" as it was held during the Dutch East Indies era, and in Indonesia there is an attitude that shows the sensitivity of the community to reject the application of such concepts;

3. If the "law" here also includes international law, then the concept of law as a means of renewing society has been implemented long before this concept was officially accepted as the basis of national legal policy.

The maritime law development in this field of port, must be prioritized in the form of a rule of positive law or legislation (law). As the message from Mochtar Kusumaatmadja that the laws and regulations made must be neutral (insensitive). Such a legal domain will not cause much controversy related to customs, religion and other primodial values. (Shidarta, Position of Thought Development Law Theory, 2012: 22). Regarding maritime law reform in the port sector, as suggested by this author, there are at least two (2) dimensions that must be seen if the maritime law will be renewed in the legal sense that lives in society, here are the dimensions intended;

1. The disharmony between the Shipping Law and the Ministerial Regulation. Of course, these various obstacles must be immediately overcome by impartial law enforcement. Because so far the implementation of the law has a tendency to prioritize the application of Ministerial Regulations, rather than implementing the Shipping Law and Government Regulation (PP).

2. With the increasing number of commercial and non-commercial ports, which are operated both by BUMN, BUMND, Private and Government, then a law concerning port is required to complete existing laws.

more than that, in the future legal compliance is required as an 'smoothly' in the establishment of port politics politics, with the quality and taste of integrity and integration of political infrastructure and superstructure based on the rule of law ('Rule of Law') which integrates ( coordinative) various stakeholder interests. (Achmad Ridwan Tentowi (et al), Politics of Law for National Port Management, 2016: 22 \&. The progressivity of Port Law in its development as a synthesis requires legal progress. in the field of Port Law, so that it can accommodate environmental needs (industry, science and technology, institutions, regulations, and Port Authority, trade), especially in the development / advancement of the Port business. Legal progress is oriented towards fulfilling the objectives / functions of the law itself: order, certainty and justice. (Satjipto Rahardjo, Legal Studies, 2002: 13) It means, towards the values of legal progress or maritime law reform, the main goal is to provide protection for the interests of the wider community (stakeholders, business people, individuals, citizens, people) or to protect Port 
Authority (OP), Port Operator, Port Business Entity (BUP) and the wider community, of course, in every port business line / activity leads to the legal ideal and rejects the status quo, and does not want to make law a dead set of rules, so that it is not innocent, but an institution that is moral, siding with the interests of many audiences.

This martyrdom legal reform is very urgent. Because the conditions are colliding (disharmony / nonconformity), between regulations with one another, between lower regulations hit with higher regulations, namely Law. If this condition is left unchecked, without any adjustments, then what happens is that the law will be left behind and business activities at the port will be hampered, so that many people, as in the 1945 Constitution, are guaranteed their welfare, this is even neglected. So thus, the values of justice are eroded, this is what causes the welfare of the people.

The legal interpretation provides an argument that the legal construction of a statutory regulation (positive law / current law) greatly determines its effectiveness (applies binding and compelling), each implementation of the law (implementation, enforcement) of the legal product to be determined. Construction of the law is related to the material content and consideration (consideration).

The legal politics going forward in the matter of establishing or reforming the Port of Maritime Affairs law must be accommodative - progressive. That is, accommodating various things that occur in the Port and have progress in ways of thinking about the law itself. Actually, this is where the meeting points between the Welfare State Theory, Justice Theory, and Development Law Theory. That is, Maritime Law will be built through the justice of its people. Maritime law reform means also making new legal rules, by accommodating various existing legal rules. Does not mean deconstructing the Law No. 17 of 2008 concerning Shipping seeks to rebuild or construct scattered literacy as contained in various Government Regulations (PP), Ministerial Regulations and Director General Regulations.

The political concept of port law in the future is the establishment of the Port Maritime Special Law. The reason why should be the establishment of the Law, because the doctrine of the State of Law necessitates the existence of legislation so this is the important role of legislation. (Ridwan HR, State Administrative Law, 2006: 4) The existence of an Act applies as a guide to guaiden in implementing state life. Therefore, it can be said that there is no single state of law without the existence of a law in that country. This maritime legal concept, can be a turning point for Indonesia to be able to improve regulations relating to maritime affairs. One of the things that must be improved is the legal regulation which until now is still unclear, not yet systematic and does not yet have legal certainty, let alone the values of justice.

Renewal of maritime law, departs from the causality between law and politics or questions about whether the law influences politics or politics that affects the law. The law of determinants of politics in the sense that political activities are regulated must be subject to the rules of law, then political determinants of the law because the law is the result or crystallization of political wills that interact and even compete with each other. It cannot be denied, too, that legal politics as a social system is in a position that is equally balanced between one another because even though law is a political decision but once the law exists, all political activities must be subject to the rule of law.

When speaking of determinants both legal and political, it is certainly caused by differences in the way experts perceive these two social subsystems, those who only view the law from the point of das sollen (necessity) or idealists cling to the view that law must be a guide in all levels of community members are included in all political activities.

Legal reform or maritime law reform is a solution to build a concept in this Dissertation, because legal development has the essence of making and updating legal materials so that they can be in accordance with needs, then the implementation of existing legal provisions including affirmation (not in the sense of negating) the function of the institution and the guidance of law enforcers. From the translation, it appears that legal politics includes the process of making and implementing laws that can show the nature and direction of where the law will be built and enforced.

The establishment of maritime law in this case the Maritime Law of the Port, among others, by transplanting Singapore Maritime Law because the substance of the law, can be implemented to manage the Port in Indonesia. Comparative studies of this law, in general, can be involved in an effort to find new ideas to solve port legal issues both in the jurisdiction of the State of Indonesia and in the jurisdiction of the comparative State. In addition, legal comparisons can also be aimed at harmonizing or unifying the law. The benefits that can be taken from the comparison of law with the Singapore State, of course, in the Maritime and Port Authority of Singapore Act Chapter 170A, is that the Indonesian State can improve the functions of the Port Authority (OP), in which the Port Authority (OP) does not have the highest authority. to coordinate with related parties. Or the benefits that can be taken is strengthening the role of the Port Authority (OP). 
The port problem is of course faced by all ports in any country, in many countries they are able to do good coordination between stakeholders in the port, for example Singapore State, so that issues related to the authority of the Port Authority (OP) such as in Indonesia do not occur or occur it will soon be easy to completed. According to Tri Budiyono, that Legal Transplantation is the takeover of legal rules, legal teachings (doctrine), structure (structure), or legal institutions (legal institutions) from another legal system or from the jurisdiction to another jurisdiction. Legal transplants can cause legal harmonization if there is conformity that includes legal rules, legal teachings, legal structures, or legal institutions. Everything depends on the substance being transplanted.

Singapore Maritime Law will be transplanted into Indonesian Maritime Law. Can this be done, while the author's answer is "can", because another dynamic of globalization is the change in patterns - patterns of relations between humans in the organization of life, especially in the fields of law and economics (business) which were originally in the local scope (concrete ) towards national, regional and even global scope (which is increasingly abstract). (Soetandyo Wignjosoebroto, Law Transplant, 2002: 135). Relations between the two countries (Indonesia Singapore), in the Maritime Law to be transplanted, of course, have increasingly contractual relationships so that people are more free to determine their own position and rights in front of others. This is what is meant by adage pacta sunt servanda in the concept of freedom of contract which is the binding for each individual or party involved in the contract. Countries, especially developing countries such as Indonesia cannot avoid this world trend, especially in the economic field (investment, trade, services, etc.) (Erman Rajagukguk, Role of Law in Development in the Globalization Era,114). Port is a large part of the maritime region, so if in Singapore the Port Authority (OP) is set clearly and specifically, then Indonesia must be able to compete in global competition. In fact, to go as a Maritime State, the main problem that has yet to be resolved is the existence of legal regulations that specifically regulate maritime affairs or the Maritime Law.

\section{REFERENCES}

Achmad Ridwan Tentowi (et al), Politik Hukum Tata Kelola Kepelabuhanan Nasional, CV. Warta Bagja : Bandung, 2016.

Erman Rajagukguk, Peranan Hukum Dalam Pembangunan Pada Era Globalisasi, Jurnal Hukum No. 11, Vol.6.

Faisal Basri \& Haris Munandar, Lanskap Ekonomi Indonesia, 2009.

Lili Rasjidi \& IB Wyasa, Hukum Sebagai Sebuah Sistem, PT. Remaja RosdaKarya : Bandung, 1994.

Mochtar Kusumaatmadja, Hukum, Masyarakat, dan Pembinaan Hukum Nasional, Lembaga Penelitian Hukum dan Kriminologi Fakultas Hukum Universitas Padjajaran: Bandung, 1976.

Mochtar Kusumaatmadja, Fungsi dan Perkembangan Hukum dalam Pembangunan Nasional, Lembaga Penelitian Hukum dan Kriminologi Fakultas Hukum Universitas Padjajaran: Bandung, tt,

Roscoe Pound, Scope and purpose of Sociological Jurisprudence, jilid XXIV vol 24 \# 8 dan 25 \# 2, 1911.

Roscoe pound, law finding through experience and reason, lectures, university of georgia press, athens. 1960.

Roscoe Pound, Social Control Through Law, New Haven: Yale University Press, 1942.

Roscoe Pound, Pengantar Filsafat Hukum, (Terj.) Muhammad radjab, Penerbit Bhratara: Jakarta, 1996.

Ridwan HR, Hukum Administrasi Negara, Raja Grafindo Persada : Jakarta, 2006.

Shidarta, Karakteristik Penalaran Hukum Dalam Konteks Ke-Indonesiaan, Penerbit CV Utomo, Jakarta, 2006.

Shidarta, Posisi Pemikiran Teori Hukum Pembangunan Dalam Konfigurasi Aliran Pemikiran Hukum: Sebuah Diagnosa Awal, Dalam Sidarta (ed), Mochtar Kusuma - Atmadja dan Teori Hukum Pembangunan, Epistema Institute - HUMA: Jakarta, 2012, hlm: 22.

Satjipto Rahardjo, Ilmu Hukum, Alumni : Bandung, 1996.

Soetandyo Wignjosoebroto, Transplantasi Hukum Ke Negara-negara Yang Tengah Berkembang, Khususnya Indonesia, dalam Hukum : Paradigma, Metode dan Masalah, Elsam dan Huma : Jakarta, 2002, 